\title{
PENGARUH KARAKTERISTIK IBU TERHADAP LAMA PERSALINAN KALA I DENGAN METODE GENTLE BITRH
}

\author{
Sab'ngatun ${ }^{1}$, Triastuti Wuryandari ${ }^{2}$ \\ Email : sabngatun@yahoo.com \\ Sekolah Tinggi Ilmu Kesehatan Mamba'ul 'Ulum Surakarta \\ Jl. Ring Road Utara KM 03 Tawangsari, Mojosongo, Jebres, Surakarta \\ Telp (0271)858172/854495
}

\begin{abstract}
Abstrak
Nyeri persalinan dapat mempengaruhi sikap psikologis ibu selama proses persalinan sehingga dapat mempengaruhi memanjangnya persalinan kala I. Salah satu faktor yang mempengaruhi persalinan ada power. Kekuatan ini dipengaruhi oleh usia, paritas dan kecemasan. Tujuan dari penelitian ini untuk mengetahui pengaruh karakteristik ibu terhadap lama persalinan kala I dengan metode gentle birth.

Desain penelitian ini menggunakan survey analitik dengan pendekatan retrospektif. Populasi dalam penelitian ini adalah semua ibu bersalin dengan metode gentle birth di klinik bidan kita Klaten pada tahun 2016, sampel diambil dengan cara quota sampling sebanyak 40 responden. Analisis menggunakan regresi ordinal.

Hasil penelitian ini mayoritas ibu bersalin dengan usia reproduksi sehat 38 responden (95\%). Paritas primipara 20 respoden (50\%). Lama persalinan kala I tergolong cepat 52,5\%. Pengaruh usia terhadap lama persalinan kala I sebesar 0,097>0,05 sehingga hasilnya tidak ada pengaruh antara usia ibu dengan lama persalinan kala I dengan metode gentle birth, sedangkan pengaruh paritas terhadap lama persalinan kala I sebesar $0,00<0,00$ yang berarti ada pengaruh antara paritas terhadap lama persalinan kala I dengan metode gentle birth. Hasil Negelkerke adalah 0,51 yang berarti bahwa secara bersama-sama 51\% lama persalinan kala I dengan metode gentle birth dipengauhi oleh paritas, sedangkan 49\% dipengaruhi oleh faktor lain.
\end{abstract}

Kata kunci : Karakteristik Ibu, Lama Persalinan Kala I

\section{Pendahuluan}

Angka kematian ibu di tahun 2015 berjumlah 4.999 kasus, sedangkan di tahun 2016 menjadi 4.912 kasus. Di tahun 2017 (semester 1) angkanya menurun lagi menjadi 1712 kasus. Selama tiga tahun, angka kematian ibu melahirkan menurun sekitar 3287 kasus. Menurut WHO, sekitar 58 ribu ibu melahirkan meninggal karena pendarahan. Yang kedua sepsis dan juga infeksi. ${ }^{1}$

Indikator Angka Kematian Ibu (AKI) utama adalah MGDs, tahun 2017 AKI adalah 88,58/100.000 kelahiran hidup. ${ }^{2}$ Penyebab AKI sangat kompleks namun penyebab langsung seperti perdarahan, partus lama, dan komplikasi aborsi tidak aman. Profil Kesehatan Indonesia menyebutkan penyebab AKI terbesar disebabkan oleh perdarahan 40\%$60 \%{ }^{3}$. Penyebab perdarahan tersebut paling sering terjadi pada saat kala empat persalinan.

Persalinan dan kelahiran merupakan peristiwa fisiologis yang normal. Persalinan merupakan proses membuka dan menipisanya leher rahim (serviks), dan janin akan turun kedalam jalan lahir. Kelahiran merupakan proses dimana janin dan ketuban didorong keluar melalui jalan lahir. Persalinan dan kelahiran normal merupakan proses 
pengeluaran janin yang terjadi pada kehamilan cukup bulan atau aterm (37-42 minggu), lahir spontan dengan presentasi belakang kepala yang berlangsung dalam 18 jam, tanpa komplikasi baik pada ibu maupun janin. ${ }^{4}$

Proses persalinan ditandai dengan adanya kontraksi uterus, dimana kontraksi uterus saat persalinan ini menimbulkan nyeri akibat terjadi kekurangan oksigen / hipoksia dari otot rahim, peregangan serviks, peregangan dari ganglia saraf plexus frakenhauster yang berdekatan dengan serviks dan vagina, penekanan pada tuba, ovarium dan peritoneum, peregangan pada ligamentum penyangga uterus, serta distensi otot-otot dasar panggul serta perineum. ${ }^{5}$

Nyeri persalinan inilah yang paling dirasakan tidak menyenangkan bahkan menakutkan pada ibu. Mengurangi rasa nyeri dapat diatasi dengan cara farmakologi (dengan obat) dan nonfarmakologi (tanpa obat). Sebenarnya rasa nyeri dan sakit bukan merupakan bagian dari proses persalinan sendiri, tetapi merupakan hasil pengaruh social, budaya, dan faktor emosi ibu. Jika rasa panik, takut, atau stress saat proses persalinan makin menguat, otak akan mengalirkan zat yang akan menutup pengeluaran endorphin. Semakin takut seseorang saat melahirkan, kian luar biasa pula sakit yang akan dirasakan. ${ }^{6}$

Nyeri dan ketakutan menimbulkan stress. Stress berakibat meningkatnya sekresi adrenalin. Salah satu efek adrenalin adalah kontraksi pembuluh darah sehingga suplai oksigen dan janin menurun. Penurunan aliran darah dapat menyebabkan melemahnya kontraksi rahim dan berakibat memanjangnya proses persalinan, sekresi adrenocorticotropic hormone (ACTH) juga meningkat, menyebabkan peningkatkan kadar kortisol serum dan gula darah. Semua efek tersebut dapat berpotensi membahayakan ibu dan janin. Nyeri persalinan dapat mempengaruhi sikap psikologis ibu, proses persalinan dan keadaan bayi baru lahir. $^{5}$

Proses persalinan yang lama menunjukkan pemanjangan kala I, adapun penyebabnya yaitu serviks gagal membuka penuh dalam jangka waktu yang layak ${ }^{7}$, persalinan lama terjadi bila fase laten lebih dari 8 jam, persalinan telah berlangsung 12 jam atau lebih tanpa kelahiran bayi, dan dilatasi serviks di kanan garis waspada partograf. Sebab terjadinya persalinan lama ini multikomplek dan tergantung pada pengawasan selagi hamil, pertolongan persalinan yang baik dan penatalaksanaannya. Salah satu faktor penyebabnya adalah wanita yang dependend, cemas dan ketakutan. ${ }^{8}$

Persalinan lama dapat membahayakan bagi ibu dan janinnya, beratnya cedera meningkat dengan semakin lamanya proses persalinan, resiko tersebut naik dengan cepat setelah 24 jam. Terdapat kenaikan pada insidensi atonia uteri, laserasi, perdarahan, infeksi, kelelahan ibu dan shok. Angka kelahiran yang tinggi semakin memperburuk bahaya ibu, sedangkan semakin lama persalinan, semakin tinggi morbiditas dan mortalitas janin, dan semakin sering terjadi asfiksia, trauma cerebri, cedera kepala, pecahnya ketuban lama sebelum kelahiran mengakibatkan terinfeksinya cairan ketuban sehngga dapat menyebabkan terinfeksinya paru-paru dan infeksi sistemik pada janin. ${ }^{9}$

Faktor yang mempengaruhi persalinan ada power (kekuatan), 
passage (jalan lahir), passanger (janin). Faktor power / kekuatan terdiri dari his / kontraksi uterus dan tenaga mengejan ibu. Kekuatan his dapat dipengaruhi oleh faktor usia, paritas, pimpinan persalinan, induksi persalinan serta rasa takut dan cemas.

Salah satu penyebab persalinan lama adalah stres/kecemasan. Untuk mengurangi kecemasan atau stress perlu dukungan dari suami, bidan maupun keluarga. Ibu bersalin membutuhkan dukungan secara fisik, mental dan emosional sebelum, selama dan setelah persalinan. Berbagai penelitian medis membuktikan bahwa dengan dukungan dalam persalinan akan memberikan manfaat $30 \%$ pengurangan dalam penggunaan analgesic, artinya disini dukungan dapat mengurangi rasa nyeri dalam persalinan. Nyeri pada proses persalinan sampai sekarang menjadi focus dalam pelayanan persalinan terbagi menjadi empat tahap dimana tahap pertama yaitu tahap pembukaan yang diakibatkan oleh kontraksi uterus. Beberapa upaya mengurangi nyeri persalinan yaitu dengan water birth, relaksasi hypnobirthing, dan meditasi. Semua teknik tersebut merupakan metode persalinan gentle birth. ${ }^{5}$

Gentle birth merupakan metode persalinan yang tenang, lembut, santun dan memanfaatkan semua unsure alamia dalam tubuh seorang manusia. Penolong dan pendamping harus membantu dengan tenang dan suara lembut, sehingga bayi lahir suasana di sekelilingnya tenag, hening dan penuh kedamaian. Hal ini bertujuan agar ibu tetap dapat mempertahankan kondisi relaksasi yang dalam selama persalinan berlangsung. ${ }^{5}$

Klinik Bidan Kita Klaten memberikan layanan persalinan
Gentle Birth. Oleh sebab itu penulis mengambil judul "Pengaruh Antara Karakteristik Ibu Dengan Lama Persalinan Kala I Dengan Metode Gentle Birth." Pada karakteristik ibu meliputi usia ibu dan paritas.

\section{Metode Penelitian}

Metode yang digunakan dalam penelitian ini adalah survey analitik dengan pendekatan retrospektif.

Populasi dalam penelitian ini adalah semua ibu yang bersalin dengan metode gentle birth pada tahun 2016. Populasi dalam penelitian ini berjumlah 54 ibu bersalin. Teknik pengambilan sampel yang digunakan adalah quota sampling.

Alat pengumpulan data pada penelitian ini adalah menggunakan master tabel yang berisi no, usia, paritas dan lama persalinan kala I. Metode pengumpulan data yang peneliti gunakan adalah data sekunder yaitu dengan melihat jumlah persalinan dengan metode gentle birth selama 1 tahun.

Analisis data bivariat menggunakan sprearman rank. Sedangkan analisis multivariate menggunakan regresi ordinal untuk mengalisis pengaruh usia dan paritas terhadap lama persalinan kala I.

\section{Hasil dan Pembahasan}

a. Tabel 1. Distribusi frekuensi karakteristik responde berdasarkan usia dan paritas

\begin{tabular}{|c|l|c|c|}
\hline No & \multicolumn{1}{|c|}{ Usia/Paritas } & frekuensi & $\mathbf{( \% )}$ \\
\hline 1 & $\begin{array}{l}\text { Usia reproduksi } \\
\text { muda }\end{array}$ & 1 & 2.5 \\
\hline 2 & $\begin{array}{l}\text { Usia reproduksi } \\
\text { sehat }\end{array}$ & 38 & 95 \\
\hline 3 & $\begin{array}{l}\text { Usia reproduksi } \\
\text { tua }\end{array}$ & 1 & 2.5 \\
\hline & Jumlah & 40 & 100 \\
\hline
\end{tabular}




\begin{tabular}{|c|l|c|c|}
\hline 1 & Primipara & 20 & 50 \\
\hline 2 & Multipara & 19 & 47.5 \\
\hline 3 & Grandemultipara & 1 & 2.5 \\
\hline & Jumlah & 40 & 100 \\
\hline
\end{tabular}

b. Tabel 2. Distribusi frekuensi responden berdasarkan lama persalinan kala I

\begin{tabular}{|c|l|c|c|}
\hline No & $\begin{array}{c}\text { Lama } \\
\text { persalinan } \\
\text { kala I }\end{array}$ & frekuensi & $(\mathbf{\%})$ \\
\hline 1 & Cepat & 21 & 52.5 \\
\hline 2 & Normal & 10 & 25 \\
\hline 3 & Lama & 9 & 22.5 \\
\hline & Jumlah & 40 & 100 \\
\hline
\end{tabular}

c. Tabel 3. Analisis Pengaruh Usia Terhadap Lama Persalinan Kala I

\begin{tabular}{|l|l|l|r|r|}
\hline \multicolumn{3}{|c|}{ Correlations } \\
\hline & & & $\begin{array}{c}\text { Lama } \\
\text { persalin } \\
\text { an kala } \\
\text { I }\end{array}$ \\
\hline $\begin{array}{l}\text { Spear } \\
\text { man's } \\
\text { rho }\end{array}$ & usia & $\begin{array}{l}\text { Correlation } \\
\text { Coefficient }\end{array}$ & 1.000 & .266 \\
\cline { 3 - 5 } & $\begin{array}{l}\text { Sig. (2- } \\
\text { tailed) }\end{array}$ & & .097 \\
\cline { 3 - 5 } & $\begin{array}{l}\text { Lama } \\
\text { persal } \\
\text { inan } \\
\text { kala I }\end{array}$ & $\begin{array}{l}\text { Correlation } \\
\text { Coefficient }\end{array}$ & .266 & 1.000 \\
\cline { 3 - 5 } & & Sig. (2- & .097 & \\
\cline { 2 - 5 } & tailed) & 40 & 40 \\
\hline
\end{tabular}

d. Tabel 4. Analisis Pengaruh Paritas Terhadap Lama Persalinan Kala I

\begin{tabular}{|l|l|l|r|r|}
\hline \multicolumn{2}{|c|}{ Correlations } \\
\hline & & & $\begin{array}{c}\text { Lama } \\
\text { persalin } \\
\text { an kala } \\
\text { I }\end{array}$ \\
\hline $\begin{array}{l}\text { Spear } \\
\text { man's } \\
\text { rho }\end{array}$ & paritas & $\begin{array}{l}\text { Correlation } \\
\text { Coefficient }\end{array}$ & 1.000 & $.694^{* *}$ \\
\cline { 3 - 5 } & & $\begin{array}{l}\text { Sig. (2- } \\
\text { tailed) }\end{array}$ & & .000 \\
\cline { 3 - 5 } & $\mathrm{N}$ & 40 & 40 \\
\hline
\end{tabular}

\begin{tabular}{|l|l|l|r|r|}
\hline \multirow{2}{*}{$\begin{array}{l}\text { Lama } \\
\text { persalin } \\
\text { an kala } \\
\text { I }\end{array}$} & $\begin{array}{l}\text { Correlation } \\
\text { Coefficient }\end{array}$ & $.694^{* *}$ & 1.000 \\
\cline { 2 - 4 } & $\begin{array}{l}\text { Sig. (2- } \\
\text { tailed) }\end{array}$ & .000 & \\
\cline { 2 - 4 } & $\mathrm{N}$ & 40 & 40 \\
\hline **. Correlation is significant at the & \\
0.01 level (2-tailed).
\end{tabular}

e. Tabel 5. Analisis Pengaruh Karakteristik Ibu (Usia Dan Paritas) Terhadap Lama Persalinan Kala I

\begin{tabular}{|l|r|}
\hline \multicolumn{2}{|c|}{ Pseudo R-Square } \\
\hline Cox and Snell & .444 \\
\hline Nagelkerke & .510 \\
\hline McFadden & .287 \\
\hline Link function: Logit. \\
\hline
\end{tabular}

Berdasarkan tabel 1, mayoritas responden adalah usia reproduksi sehat sebanyak 38 responden (95\%) dan primiparitas sebanyak 20 responden (50\%). Dimana usia reproduksi sehat untuk hamil dan melahirkan adalah di usia 20-35 tahun. Menurut dokter Didi Danukusumo, SpOG, penyulit yang mungkin terjadi pada kehamilan diusia lebih dari 35 tahun selain menurunnya kesuburan, juga terdapat ancaman pada ibu maupun janinnya. Resiko pada ibu mengalami hipertensi, diabetes mellitus, persalinan engan tindakan Caesar sampai kematian, sementara resiko terhadap janin bisa terjadi peningkatan resiko keguguran, kelainan janin akibat kelainan kromosom, kematian hasil konsepsi dan janin lahir mati. Persalinan di bawah usia 20 tahun beresiko meningkatkan kematian neonatal, bayi dan balita. ${ }^{11}$

Berdasarkan tabel 2. Mayoritas responden proses persalinan kala I tergolong cepat. Menurut Manuaba (2010) menyatakan bahwa persalinan adalah proses pengeluaran hasil konsepsi (janin dan uri) yang telah cukup bulan atau dapat hidup di luar kandungan melalui jalan lahir, dengan bantuan atau tanpa bantuan. Kala I 
adalah kala pembukaan yang berlangsung antara pembukaan nol sampai pembukaan lengkap. Lama kala I untuk primiparitas berlangsung 12 jam sedangkan multiparitas 8 jam. $^{12}$

Persalinan dengan gentle birth ini memberikan keuntungan pada ibu untuk melewati proses persalinan dengan tenang, rileks, dapat mengelola dan mengendalikan nyeri karena kontraksi, meminimalisir trauma dalam persalinan sehingga ibu terbebas dari ketakutan dan kecemasan, dengan demikian waktu persalinan menjadi lebih singkat. ${ }^{5}$

Berdasarkan tabel 3. Pengaruh usia terhadap lama persalinan kala I dengan taraf signifikan 5\% hasilnya 0,097 sehingga $0,097>0.05$ berarti Ho diterima yang berarti tidak ada pengaruh antara usia dengan lama persalinan kala I dengan metode gentle birth.

Hasil penelitian ini usia tidak berpengaruh terhadap lama persalinan kala I dengan metode gentle birth dikarenakan metode gentle birth member manfaat bagi ibu melewati persalinan dengan nyaman tenang dan dapat mengendalikan rasa sakit sehingga dengan kondisi ibu yang lebih tenang dan rileks maka proses persalinan akan berjalan dengan lancar bahkan menjadi lebih cepat dari biasanya. Dengan usia ibu berapa saja asalkan seorang ibu bisa mengelola dan mengendalikan stress, kecemasan, nyeri persalinan maka seorang ibu bersalin dapat melewati proses persalinan dengan lancar.

Hasil penelitian Surtiningsih (2017) dilihat dari usia yang paling cepat lama persalinan kala I adalah pada usia 20-35 tahun dengan rata-rat waktu 512 menit, sedangkan dari faktor paritas yang paling cepat adalah paritas grandemultipara (lebih dari 4) dengan rerata waktu 424 menit. Jika dilihat dari masing-masing faktor secara teliti nampak adanya perbedaan pada lama waktu persalinan akan tetapi dari hasil uji hubungan didapatkan tidak ada hubungan antara faktor umur, paritas,
Tinggi Fundus Uteri, Umur Kehamilan dan Berat Bayi Lahir terhadap lama waktu persalinan kala I ( $\mathrm{p}$ value 0,257 $0,746>0,05) .^{13}$

Hasil penelitian Sadiyah (2014) usia > 35 tahun mempunyai nilai peluang 0,024 yang berarti bahwa terdapat pengaruh usia terhadap lama persalinan kala I fase aktif. Semakin tua umur seseorang, maka risiko persalinan kala I fase aktif yang memanjang akan semakin meningkat. Pada usia $>35$ tahun kondisi fisik ibu hamil menurun sehingga kontraksi yang dihasilkan otot rahim tidak maksimal sehingga meningkatkan resiko persalinan lama. ${ }^{14}$

Berdasarkan tabel 4. Pengaruh paritas terhadap lama persalinan kala I dengan taraf signifikan 5\% hasilnya 0,00 sehingga $0,00<0,05$ berarti Ho ditolak, artinya ada pengaruh yang signifikan antara paritas dengan lama persalinan kala I dengan metode gentle birth.

Hasil penelitian ini dari paritas primi mayoritas persalinan kala I berlangsung cepat $/<12$ jam sebanyak 17 orang hal ini bisa disebabkan karena primigravida berada pada usia reproduksi sehat dimana kondisi fisik ibu masih kuat sehingga kontraksi yang dihasilkan otot rahim menjadi maksimal sehingga mempercepat proses persalinan.

Hasil penelitian Hasyim (2014) bahwa hasil uji stattistik diperoleh $\mathrm{p}$ value 0,002 sehingga $p<\alpha=0,05$ berarti ada hubungan antara paritas ibu dengan kejadian persalinan lama di RSUD Pringsewu tahun 2014, secara Secara statistik diperoleh nilai $\mathrm{OR}=2,051(\mathrm{CI}=$ 1,311-3,209) bahwa responden paritas ibu yang berisiko mempunyai peluang 2,051 kali untuk mengalami persalinan lama, dibandingkan dengan paritas ibu yang tidak berisiko (tidak mengalami persalinan lama). ${ }^{15}$

Berdasakan tabel 5. Secara bersama-sama usia tidak mempengaruhi lama persalinan kala I dan paritas dapat mempengaruhi lama persalinan kala I. 
hasil Negelkerke adalah 0,51 yang berarti bahwa secara bersama-sama $51 \%$ lama persalinan kala I dengan metode gentle birth dipengauhi oleh paritas, sedangkan $49 \%$ dipengaruhi oleh faktor lain.

Faktor yang mempengaruhi persalinan yaitu keadaan fisik secara umum dan emosi, besarnya janin, presentasi janin, kualitas dan jenis his persalinan, keadaan serviks, anatomi dan volume uterus, dan arsitektur tulang panggul. Dari hasil penelitian Larosa (2009) bahwa terdapat perbedaan lama persalinan antara primipara dan multipara pada kala I, hal itu dikarenakan adanya perbedaan pada dilatai serviks antara primipara dan multipara, dimana primigravida akan mengalami penipisan serviks dalam 3 minggu terakhir kehamilannya dan suatu penipisan serviks yang sempurna akan terjadi pada saat memasuki persalinan. Sedangkan pada multigravida dan grandemultigravida sering terjadi perlunakan serviks tanpa didahului dengan penipisan dari serviks, pasien multipara akan memasuki persalinan dengan serviks yang lunak dimana penipisan serviks belum terjadi dengan baik, namun pembukaan dan penipisan yang cepat akan terjadi dalam waktu bersamaan pada saat kala II. ${ }^{16}$ Hal ini sesuai dengan teori bahwa penipisan serviks dapat terjadi pada akhir kehamilan atau tidak terjadi hingga persalinan dimulai, pada wanita nulipara, serviks biasanya tidak akan berdilatasi hingga penipisan sempurna, sedangkan pada multipara penipisan dan dilatasi dapat terjadi secara bersamaan dan kanal kecil dapat teraba di awal persalinan. ${ }^{17}$

Berdasarkan hasil penelitian ini rata-rata lama persalinan dengan metode gentle birth baik primipara maupun multipara terbilang lebih cepat, dimana rata-rata lama persalinan kala I pada primipara adalah 12 jam dan multipara 8 jam, hasil penelitian ini menunjukkan rata-rata lama persalinan kala I primipara 9 jam dan multipara 7,9 jam. Hal ini dikarenakan metode persalinan gentle birth berfungsi untuk mengendalikan rasa nyeri, ibu bisa merasa tenang dan bebas dari kecemasan dan ketegangan. Dalam persalinan gentle birth terdapat beberapa metode untuk mengurangi nyeri persalinan diantaranya dengan hipnobirthing dan waterbirth. Konsep gentle birth yang membantu persalinan yang tenang, lembut, santun, dan memanfaatkan semua unsur alami dalam tubuh seorang manusia meyakinkan setiap perempuan memiliki potensi untuk menjalani proses persalinan sealamiah mungkin, tenang, dan nyaman, sehingga nyeri persalinan dapat diminimalkan. $^{5}$ Jika seorang ibu bersalian dapat mengontrol nyeri persalinan, maka proses persalinan dapat berjalan dengan lancar. Lama persalinan bisa dipengaruhi oleh nyeri persalian, dimana nyeri, kekhawatiran dan ketakutan dapat menyebabkan respon simpatis sehingga curah jantung dapat menjadi lebih besar, hal ini mempengaruhi pelepasan ketokolamin. Adrenalin yang terdiri dari epinefrin yang terdiri atas $80 \%$ ketokolamin, memiliki efek mengurangi aliran darah uterus sehingga menyebabkan penurunan aktivitas uterus, jika aktivitas uterus berkurang dapat menyebabkan lambatnya pembukaan serviks sehingga persalinan menjadi lama. ${ }^{17}$ Salah satu cara analgesia untuk mengatasi nyeri persalinan dengan hidroterapi, dimana panas yang diberikan akan memberikan efek anti spasme. ${ }^{17}$ Hidroterapi memiliki keuntungan : waktu persalinan lebih sedikit (cepat); menurunkan insiden trauma saluran genetal. ${ }^{5}$

\section{Kesimpulan}

Hasil

penelitian ini menunjukkan tidak ada pengaruh antara usia dengan lama persalinan kala I dengan metode gentle birth; 
ada pengaruh yang signifikan anatara paritas dengan lama persalinan kala I dengan metode gentle birth dan secara bersama-sama faktor yang mempengaruhi lama persalinana kala I dengan metode gentle birth sebesar $51 \%$ dipengaruhi oleh paritas sedangkan $49 \%$ dipengaruhi oleh faktor lain.

\section{Daftar pustaka}

[1] Depkes. Capaian Kinerja Kemenkes RI tahun 2015. 2017. 2017 http://www.depkes.go.id/artic le/view/17081700004/-inilahcapaian-kinerja-kemenkes-ritahun-2015--2017.html

[2] Dinkes Jateng. Rakerkesda Kadinkes. 2018 https://www.dinkesjatengprov .go.id/v2015/index.php/comp onent/content/article/39rokcontent/frontpage/460laporan-kepala-dinas$\underline{\text { rakerkesda-2018 }}$

[3] Yulianingsih. Asuhan kegawatdaruratan dalam Kebidanan. Jakarta.Trans Indo Medika. 2009

[4] Saifuddin, Abdul Bari. Buku Panduan Praktis Pelayanan Kesehatan

Maternal dan Neonatal. Jakarta: Yayasan Bina Pustaka Sarwono Prawirohardjo. 2011

[5] Aprilia, Y; Richmont, B, Gentle Bitrh Melahirkan Nyaman Tanpa Rasa Sakit. Jakarta : Gramedia, 2011

[6] Prawiroharjo, Sarwono. Ilmu Kebidanan. Jakarta : Yayasan Bina Pustaka Sarwono Prawiroharjo, 2010
[7] Oxorn, Harry. Fisiologi dan Patologi Persalinan. Jakarta: Yayasan

Essentia Medica. 2010

[8] Wiknjosastro, Hanifa. Ilmu Kandungan. Jakarta: Yayasan Bina Pustaka Sarwono Prawirohardjo. 2010

[9] Mochtar, Rustam. Sinopsis Obstetri Jilid I. Jakarta : EGC. 2011

[10] Purwaningsih, W \& Siti F. Asuhan Keperawatan Maternitas. Jogjakarta : Nuha Medika. 2010

[11] Santosa, AB., Inilah Usia Rawan Hamil dan Potensi Risiko pada Ibu dan Anak, 2019.

http://www.tribunnews.com/k esehatan/2013/04/07/inilahusia-rawan-hamil-danpotensi-risiko-pada-ibu-dananak

[12] Manuaba, I.B.G, dkk. Ilmu Kebidanan, penyakit kandungan dan KB. Jakarta: EGC. 2010

[13] Surtiningsih. Faktor-Faktor Yang Mempengaruhi Lama Waktu Persalinan Di Puskesmas Klampok 1 Kabupaten Banjarnegara. 2017 . Skripsi. Bidan Prada: Jurnal Ilmiah Kebidanan, Vol. 8 No. 2 Edisi Desember 2017, hlm. 101-115 file://C:/Documents\%20and $\%$ 20Settings/PRIVATE/My $\%$ 20Documents/Downloads/31 1-532-1-SM\%20(1).pdf

[14] Sadiyah, N dan Melaniani, S. Pengaruh Faktor Reproduksi Ibu dan Anemia Terhadap Lama Persalinan Kala I Fase Aktif. Surabaya : Unair. 2014 
Jurnal Biometrika dan Kependudukan, Vol. 3, No. 2 Desember 2014: 136-142 http://journal.unair.ac.id/dow nload-fullpapersbiometrikc3e4cd98d8full.pdf

[15] Hasyim, DI dkk, Hubungan Paritas Dengan Kejadian Partus Lama Di RSUD Pringsewu Tahun 2014. http://webcache.googleuserco ntent.com/search?q=cache:JX YpsiMFPwJ:ojs.akbidylpp.a c.id/index.php/Prada/article/d ownload/189/148+\&cd=2\&hl $=\mathrm{id} \& \mathrm{ct}=\mathrm{clnk} \& \mathrm{gl}=\mathrm{id}$

(16) Larosa, Putri. Perbedaan Lama Persalinan Antara
Primipara Dengan Multipara Di RSUD dr Moewardi Surakarta. Skripsi. Surakarta : Universitas Sebelas Maret. 2009

https://digilib.uns.ac.id/doku men/detail/15152/Perbedaanlama-persalinan-antaraprimipara-dengan-multiparadi-RSUD-Dr-MoewardiSurakarta

[17] Myles. Buku Ajar Bidan Myles Ed.14. Jakarta : EGC. 2014 